\title{
Production Factors and Fisheries Business Feasibility Study at Nusantara Kejawanan Fishing Port of Cirebon City
}

\author{
Euis Dasipah ${ }^{1}$, Tuti Gantini ${ }^{2}$, Uen Priatna Sunarya ${ }^{3}$ \\ \{euisdasipah@gmail.com ${ }^{1}$, gantini.tuti.1963@gmail.com², uenpriatnsunarya@gmail.com ${ }^{3}$ \} \\ Faculty of Agriculture, Universitas Winaya Mukti ${ }^{1}$
}

\begin{abstract}
The efforts of fishermen to increase their income include increasing their catch production. Operational capture activities get satisfactory results, usually supported by vessel capacity, number and type of fishing gear, type of engine used and number of fishermen (Juwarti, 2003). In addition, the sailing frequency and season also affect fish catches. The puIDRose of this study is 1) Knowing the catch growth trend. 2) Knowing the production factors that affect the catch 3) Analyzing the feasibility of capture fisheries in the Archipelago Fisheries Port (PPN) of the City of Cirebon. The research method used is quantitative descriptive format, using quantitative data and qualitative data. Research shows that captive fishery products are PPN, the biggest being Cirebon squid. In addition, there are increasing commodities such as crabs, shrimp and red snapper. The growth of capture fisheries in PPN Cirebon city championship period 2013-2017 as a whole has increased. Catch growth follows the regression equation model: $\mathrm{Yt}=15172,200-3826,500 \mathrm{~T}+2103,000 \mathrm{~T} 2-238,500 \mathrm{~T} 3$. The biggest income is obtained from the squid commodity, while the commodities are fish, shrimp, and shellfish below. The income of shipowners increases every year. The ship crew (ABK) income still does not reach the minimum standard of living feasibility every year. With these conditions, the lives of fishermen are still classified as low economic levels, with minimum income. Captured fishery income (IDR / year) is influenced by variable size of ship (Gross ton), fuel cost (IDR / year), cost of financing (IDR / year) and number of crew (person) by following the regression model: $\mathrm{Y}=-309,369+6,049 \mathrm{X} 1+0.777 \mathrm{X} 2$ $+0.069 \mathrm{X} 3+73,012 \mathrm{X} 4+\mathcal{E}$. Partially, the size of the vessel (gross ton) of fuel costs and the number of crew members affect the income of the capture fisheries business, but the logistical costs do not affect the Captive Fish Product Revenues. Simultaneously, the three influential variables simultaneously on income from the business of catching fish. In terms of business feasibility, based on the $\mathrm{R} / \mathrm{C}$ ratio, capture fisheries are very efficient. In Break Even Point 2.59 Years, the capture fisheries business is very feasible.
\end{abstract}

Keywords: growth, production factors, business feasibility

\section{Introduction}

Efforts can be made to increase fishermen's income, among others, by increasing their catch production. One way to increase this production is to try to produce high-yielding capture units in the quantity and catch. Catching activities get satisfactory results, usually supported by the capacity of the vessel, the number and type of fishing gear, the type of engine used and the number of fishermen [1]

In addition, the sailing frequency and season also affect fish catches [2]. The life of fishermen in the Nusantara Fisheries Port (PPN) The city of Cirebon is a part of an urban activity area with the majority of the population working as fishermen [3]. The lack of income of the majority of the population obtained from livelihoods as fishermen has caused the majority of the population around the PPN in the City of Cirebon to be included in the category of Low Income Families. 
Several factors are estimated to influence the trend of trends in marine fish catches including the number of boats, the number of fishing gear, the type of engine used [4], the number of trips and the number of fishermen on average per year which is followed by the growth rate of catch production increase.

Production factors that affect the catch include; experience of fishermen, number of fishing trips, amount of fuel and storage space capacity [5]. In addition, in making arrests, fishermen must pay attention and preserve marine resources so that there is no overfishing [6] caused by large-scale fishing of marine resources.

In addition there are differences in sea fish catches influenced by the season [7] where the fish season is higher. The biggest operational cost of all costs incurred by fishermen every time a trip is the cost of purchasing fuel [8].

The puIDRose of this study is 1) To find out the growth trend of marine fish catches in the Nusantara Kejawanan Port of the City of Cirebon. 2) Knowing the production factors that affect the catch at the Nusantara Fisheries Port of the City of Cirebon. 3) Analyzing the feasibility of capture fisheries in the Nusantara Kejawanan Port of the City of Cirebon.

\section{Research Method}

The method used in this research is quantitative descriptive, using quantitative and qualitative data [9]. This research was conducted to measure the production factors in capture fisheries and fishermen's life in the Cirebon Fisheries Port of Cirebon.

\subsection{Research Variables}

The variables measured in this study are:

a. The growth of catch by fishermen is influenced by the size of the catch at a certain time.

b. Production factors that affect the catch include: ship capacity, number of crew members, experience of fishermen, fuel, supplies and capacity of fishing gear.

c. Based on business feasibility, the investment costs obtained consist of:

Ship investment consists of shipbuilding, propulsion engines, cooling machines and fishing gear. Investment in legality / licensing for business entity (SIUP), SIPI, tax and retribution and mooring fees. Ship operational investment consists of fuel, fishing gear, supplies and number of crew members. And maintenance investment consists of ship maintenance, engine maintenance, engine coolant maintenance, maintenance of fishing gear. The types of data collected are primary and secondary data, where primary data is obtained through observation, questionnaires and interviews with fishermen and ship owners in the Nusantara Fisheries Port of the City of Cirebon, while secondary data is obtained from relevant agencies, literature studies on research results before or other studies.

\subsection{Collecting Data Procedure}

a. Determine the respondent (boat owner and crew).

b. Determine parties directly related to capture fisheries activities, such as port employees, fish auction staff, village officials, catch buyers, and marine and fisheries services. 
c. Furthermore, questionnaires were distributed to the boat owners and crew members

d. Structured interviews are conducted.

e. Field observations were carried out

Fisheries business operators, consisting of 219 boat owners, 1981 crew members, port workers and fish processing industries as many as 1635 people. In this study, respondents were restricted to ship owners and crew members.

From the fishing population, as many as 219 boat owners were taken as many as 40 people as respondents [10].

From the population of ABK fishermen, as many as 1981, 85 people were taken as random respondents. Respondents were taken when the respondent carried out activities on the ship [11].

\subsection{Analysis Design and Hypotheses Test}

Data on capture fish production are analyzed graphically to see trends in growth trends. Then analyzed using cubic regression analysis, using the formula

Cubic Model $\quad: \mathrm{Y}_{\mathrm{t}}=\mathrm{B}_{0}+\mathrm{B}_{1}(\mathrm{~T})+\mathrm{B}_{2}(\mathrm{~T})^{2}+\mathrm{B}_{3}(\mathrm{~T})^{3}$

Data of production factors obtained will be analyzed using multiple linear functions, where $\mathrm{Y}$ is the sale of all capture fisheries commodities, X1 is the number of crew members, X2 is supplies and X3 is fuel oil. To test hypotheses, both partially and simultaneously, multiple linear regression is used. multiple linear regression analysis for capture fisheries income (IDR. / year) as follows:

$$
Y=\alpha+\beta 1 \times 1+\beta 2 \times 2+\beta 3 \times 3 \text {. }
$$

Description :

Y : Income from capture fisheries (IDR. / Year)

$\alpha \quad$ : Constant

X1 : Size of ship (gross ton)

X2 : Fuel Cost (IDR/Tahun)

X3 : Supplies (IDR. / Year)

X4 : Number of crew members (people)

Bo $\quad$ : The constant, is the bound value in this case $\mathrm{Y}$ when the independent variable is 0 (X1 ... X5 = 0)

$\beta 1 \quad$ : Multiple variable independent regression coefficient X1 against dependent variable $\mathrm{Y}$, if other independent variables are considered constant

$\beta 2 \quad$ : The independent variable multiple regression coefficient X2 against the dependent variable $\mathrm{Y}$, if the other independent variables are considered constant

$\beta 3$ : The independent variable multiple regression coefficient X3 against the dependent variable $\mathrm{Y}$, if the other independent variables are considered constant

$\beta 3 \quad$ : Free variable multiple regression coefficient $\mathrm{X} 4$ to dependent variable $\mathrm{Y}$, if other independent variables are considered constant

$\in \quad$ : Disturbing factors outside the model

Business feasibility is analyzed by financial analysis. Feasibility seen from:

a. $\mathrm{R} / \mathrm{C}$ Ratio

$\mathrm{R} / \mathrm{C}$ ratio (Revenue Cost Ratio) is business efficiency, namely the size of the ratio between business income $($ Revenue $=\mathrm{R})$ and Total Cost $($ Cost $=\mathrm{TC})$. Total costs consist of fixed costs and variable costs. With an $\mathrm{R} / \mathrm{C}$ value, it can be seen whether a business is profitable or not profitable. Efforts are said to be efficient (profitable) if the value of $\mathrm{R} / \mathrm{C}>1$. The formula: 
$\mathrm{R} / \mathrm{C}$ ratio $=$ Total Revenue $(\mathrm{R}):$ Total Production Cost $(\mathrm{TC})$

b. Benefit Cost Ratio

$\mathrm{B}$ / C Ratio (Benefit Cost Ratio) is a measure of the ratio between income and total production costs $($ Cost $=\mathrm{C})$. $\mathrm{B}$ means Benefit, while $\mathrm{C}$ means cost. The formula for calculating $\mathrm{b} / \mathrm{c}$ ratio is: $\mathrm{B} / \mathrm{C}$ ratio $=$ Total Revenue $(\mathrm{B})$ : Total Production Cost $(\mathrm{TC})$

If the $\mathrm{B} / \mathrm{C}$ ratio $>1$ then the business is feasible to continue, but if the $\mathrm{B} / \mathrm{C}$ ratio $<1$ then the business is not feasible or loses.

c. Break Event Point (BEP)

It is defined as a point where costs or expenses and income are balanced so that there are no losses or gains [12], BEP equations or formulas are:

BEP (in Units) = Fixed Production Costs / (Selling Prices per Unit - Variable Costs per Unit)

\section{Result and Discussion}

PPN captive fishery products, Cirebon consists of fish, shrimp and squid. For more details, see Table 1.

Tabel 1. PPN Capture Fisheries Cirebon Vocational Period 2013 - 2017

\begin{tabular}{clrrrrr}
\hline \multirow{2}{*}{ No } & Commodity & \multicolumn{5}{c}{ Production (Tons) } \\
\cline { 2 - 6 } & & 2013 & 2014 & 2015 & 2016 & 2017 \\
\hline 1 & Squid & 5.665 & 5.998 & 6.574 & 7.614 & 7.908 \\
2 & Crab & 916 & 994 & 1.036 & 1.556 & 1.872 \\
3 & Kemang & 132 & 141 & 134 & 166 & 149 \\
4 & Kurisi & 1.264 & 1.555 & 1.711 & 1.627 & 1.144 \\
5 & Shrimp & 1.105 & 1.204 & 1.307 & 1.118 & 1.543 \\
6 & Mackerel & 750 & 836 & 926 & 1.260 & 1.412 \\
7 & Pomfret & 875 & 941 & 1.012 & 1.642 & 1.359 \\
8 & Pompano & 1.154 & 1.257 & 1.356 & 1.975 & 1.564 \\
9 & Red Snapper & 621 & 702 & 764 & 911 & 1.025 \\
10 & White Snapper & 524 & 549 & 614 & 523 & 604 \\
11 & Oyster & 122 & 175 & 253 & 187 & 140 \\
\hline & Total & 13.128 & 14.352 & 15.687 & 18.579 & 18.720 \\
\hline
\end{tabular}

Based on Table 1. it is known that fishery products are captured in Vocational PPN, the largest being squid. In addition, there are increasing commodities such as crabs, shrimp and red snapper. Captured fisheries are used to meet domestic consumption and exports. Graphically, the results of the analysis of trends in overall capture fisheries production per year for the 2013-2017 period in PPN, the Cirebon Volunteers are shown in Figure 1. 


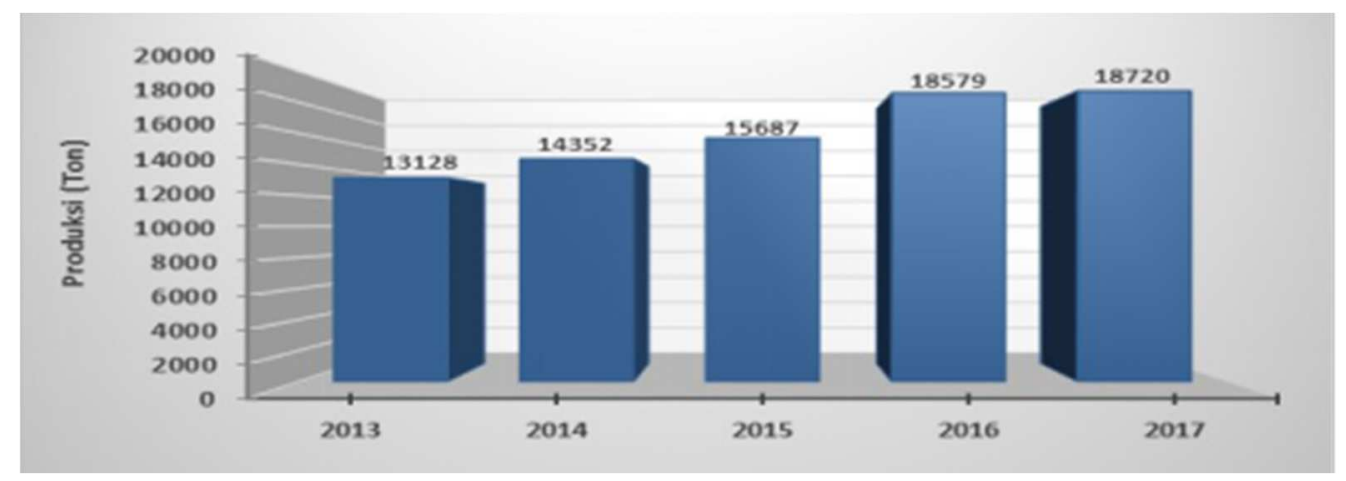

Figure 1. Overall Trends in Capture Fisheries for the Year 2013-2017 in PPN Cirebon

The graph shows that capture fisheries production every year starting from 2013 until 2017 tends to increase. Furthermore, regression testing is forecasted on 4 regression models, namely linear, logarithmic, quadratic and cubic. From the four regression models the best fit regression model is selected by looking at the highest $\mathrm{R}$ Square value or looking at the regression model graph by looking at the distribution of points on the graph. The model that meets the requirements for forecasting is a model where the residuals are free of fit values. Residuals that are free of fit values are the distribution of points with no clear pattern. The fit curve output visually gives an assessment of the fit of each model to the observed value. From this plot, it can be seen that the cubic model is better approaching the tendency of the data than the linear, logarithmic and quadratic models (Figure 2).

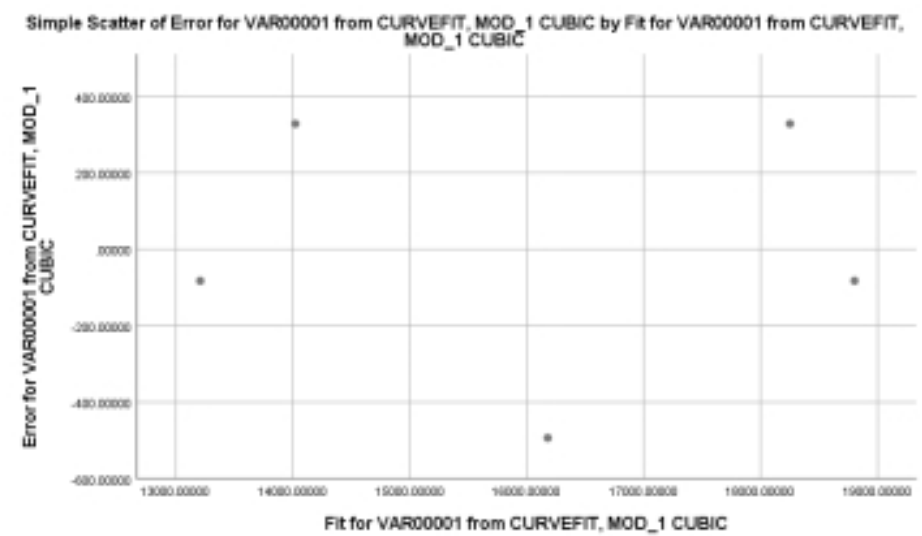

Figure 2. Cubic Model of the Relationship Between Production and Year Period 


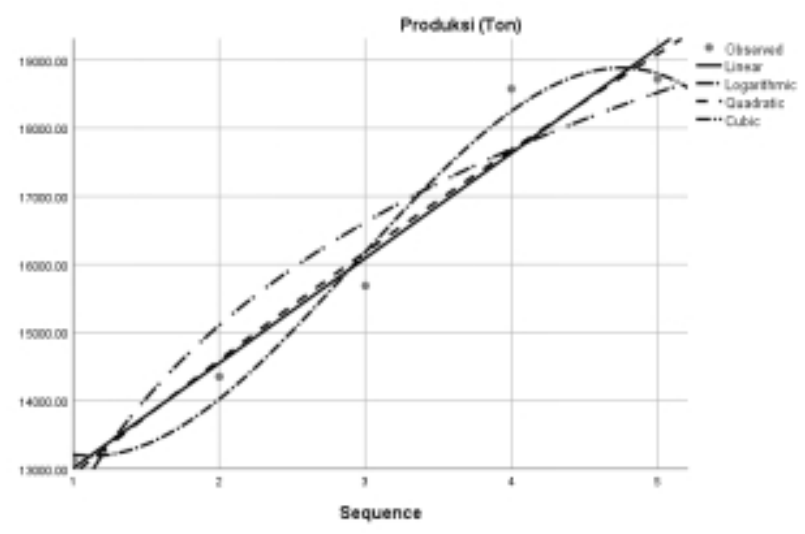

Figure 3. Cubic Model of Trends in Capture Fisheries Growth Trends

The cubic model shows that the relative points spread irregularly so that a decision can be made that the cubic model is the best model between linear, logarithmic and quadratic models with graphs (Figure 3). Thus, the data regression equation model of growth trends in capture fisheries production is: $\mathrm{Y}_{\mathrm{t}}=15172,200$ $-3826,500 \mathrm{~T}+2103,000 \mathrm{~T}^{2}-238,500 \mathrm{~T}^{3}$

\subsection{Socio-Economic Status of Ship Crews}

With the number of Ship Crews (ABK) who depend their lives on capture fisheries is a very promising potential. In 1 (one) year, on average, they go to sea 3 (three) times. Once fishing for 3 (three) months. So that the income for 9 (nine) months to finance their lives and family for 1 year. This is what makes his income still in a low standard of living.

Judging from the distribution, generally the respondents (ABK) have relatively low levels of education, namely elementary school at $38.45 \%$, junior high school at $33.39 \%$ and high school at $14.16 \%$. Judging from the age distribution, the respondents (ABK) aged between 20 to 30 years were $22.26 \%, 31$ up to 40 years as many as $56.66 \%$ and 41 to 50 years as many as $7.8 \%$. If seen from the distribution, the age of 31 to 40 years is the largest percentage of ABK.

ABK's experience ranged from 6 to 21 years with an average of 11.7 years as ABK. With experience that has been long enough, it is expected that productivity will be higher which will ultimately increase the income of fishermen. Furthermore, it is known that ABK income ranges from IDR. 32,750,000 / year up to IDR. 14,850,000, - / year. Expenditures for ABK range from IDR. 29,750,000 / year up to IDR. 15,150,000 / year. With these conditions, the lives of fishermen are still in a relatively low economic level, with a minimum income of IDR. 1,237,500, - / month and a maximum of IDR. 2,729,167, - / month.

Analysis of Multiple Linear Regression for Capture Fisheries Income The results of data analysis based on the calculation of SPSS version 25.0 obtained multiple regression equations $\mathrm{Y}=-309,369+6,049 \mathrm{X}_{1}+$ $0,777 \mathrm{X}_{2}+0,069 \mathrm{X}_{3}+73,012 \mathrm{X}_{4}+\varepsilon$

\subsection{The multiple regression equation means:}


a. Every increase of 1 gross ton of ship size will increase the Catch of Fish Products by IDR. 6.049 assuming the BBM Cost, Logistics Cost and the number of ABK are constant.

b. Every increase in IDR. 1 in fuel costs will increase the yield of capture fish by IDR. 0.777 assuming the Size of the Ship, Logistics Cost and the Number of Crews are constant.

c. Every increase of IDR. 1 in Logistics Costs will increase the Catch of Fish Products by IDR. 0.069 assuming the size of the ship, fuel costs and the number of crews are constant.

d. Every increase of 1 person, the number of crew members will increase the yield of capture fish by IDR. 73,012 assuming Ship Size, Fuel Cost and Logistics Cost are constant.

\subsection{Capture Fisheries Business Income}

The results of capture fisheries are the products of fish and other marine commodities that have been captured and marketed by fishermen. The marine commodities that dominate the VOC PPN are squid.

In this study the fishing gear used was gill net for fish and squid fishing gear. Both of these fishing gear are fishing equipment that are commonly used by crew members to catch fish and other marine commodities.

The overall growth trend in capture fisheries production for the period 2013 to 2017 has experienced increasing growth. In 2013, capture fisheries production amounted to 13,128 tons, in 2017 it reached 18,720 tons. The increase in growth is influenced by the number of ships and market demand.

The biggest income is obtained from the squid commodity, while the commodities are fish, shrimp, and shellfish, which are below the total value of 4.15 billion per year. The lowest income is IDR. 990,000,000 per year.

When viewed from the trends in the development of capture fisheries, there are some commodities that increase in yield such as crabs, shrimp and red snapper, but there are also decreasing yields such as shellfish, fish cakes, crumbs, pomfret and curry.

If seen from the results of catching fish, each respondent (ship owner) is different. The difference in operating results of each ship owner is usually influenced by the capacity of the ship. The greater the capacity of the ship, the greater the results obtained.

Production Factors Affecting Capture Fisheries Based on the results of data analysis based on the calculation of SPSS version 25.0 multiple regression equations are obtained:

$\mathrm{Y}=-309,369+6,049 \mathrm{X}_{1}+0,777 \mathrm{X}_{2}+0,069 \mathrm{X}_{3}+73,012 \mathrm{X}_{4}+\varepsilon$

Description :

$\mathrm{Y}=\mathrm{Y}$ (Catching Fish Products) (IDR. / Year)

$\mathrm{X}_{1}=$ Ship Size (Gross ton)

$\mathrm{X}_{2}=$ Fuel Cost (IDR / year)

$\mathrm{X}_{3}=$ Logistics Costs (IDR / Year)

$\mathrm{X}_{4}=$ Number of crew members (people)

$\varepsilon=$ Errors in multiple regression models

The multiple regression equation means:

a. Every increase of 1 gross ton of ship size will increase the Catch of Fish Products by IDR. 6.049 assuming the BBM Cost, Logistics Cost and the number of ABK are constant.

b. Every increase in IDR.1 The fuel cost will increase the capture fish yield of IDR. 0.777 assuming the Size of the Ship, Logistics Cost and the Number of Crews are constant. 
c. Every increase in IDR.1 Logistics Costs will increase the Catch of Fish Products by IDR. 0.069 assuming the size of the ship, fuel costs and the number of crews are constant.

d. Every increase of 1 person, the number of crew members will increase the catch of fish products by IDR. 73,012 assuming Ship Size, Fuel Cost and Logistics Cost are constant.

Based on the calculation of SPSS version 25.0, the determination coefficient is 0.918 , which means that the Capture Fish Product of $91.8 \%$ is determined by the size of the vessel, fuel costs, logistics costs and the number of crew while the remaining $8.2 \%$ is influenced by other variables not examined. Thus, the effect of ship size, fuel costs, logistics costs and the number of crew members on the results of capture fish is $91.8 \%$. In capture fisheries, external factors are very small (less than $10 \%$ ) which can affect the success of capture fisheries.

Based on partial testing of the tested variables it is known that:

a. The size of the vessel is partially very influential on the results of capture fish

b. Partial fuel costs have an effect on the results of catching fish

c. Logistics costs are not partially affected by the results of catch fish.

d. The number of crew members is partially affected by the results of catch fish.

In simultaneous testing, ship size, fuel costs, logistic costs and the number of crew members have a simultaneous influence on the results of catch fish. Based on these data, ship size is a very important variable in determining the success of capture fisheries. In addition, the need for fuel is a vital variable in capture fisheries. Ships with capacities below 30 GT get fuel subsidies of 30 tons at IDR prices. 5650, - per liter. Whereas ships with a capacity of more than $30 \mathrm{GT}$ do not get fuel subsidies, so ship owners must buy $\mathrm{BBM}$ at industrial prices, which is equal to IDR. 10,600 - per liter. Under these conditions, the boat owner must provide fees for BBM between IDR. 420,000,000, up to 1,749 billion per year.

The influence of the provisioning costs on the income of the capture fisheries business partially based on the calculation of SPSS Version 25.0 obtained tcount of 0.048 with a significance value of 0.962 . Thus $\mathrm{t}$ count $(0.048)<\mathrm{t}$ table $(2.028)$ or significance value $(0.962)>\mathrm{a}(0.05)$, which means that H0 is accepted. This shows that the Logistics Cost is partially not affected by the income of the capture fish. The size of the logistics costs is not affected by the catch.

Based on the survey results, ship owners in carrying out their business issued a cost of logistics (logistics) ranging from IDR. 300,000,000 up to IDR 600,000,000 per year. When viewed from the portion of financing, it is relatively small compared to the others.

Furthermore, the extent of the effect of the number of crew members on the income of capture fisheries business is partially, based on the calculation of SPSS Version 25.0 obtained tcount of 3.956 with a significance value of 0,000 . Thus $t$ count $(3.956)>t$ table $(2,028)$ or significance value $(0,000)<a(0.05)$, which means $\mathrm{H} 0$ is rejected. This shows that the number of crew members is partially affected by the capture of income from fish.

The number of crew members brought by the captain ranged from 10 to 24 people. This amount is very relative depending on the capacity of the ship. Based on the results of the method, data is obtained that the crew is generally paid daily. ABK payments range from IDR. 30,000 - up to IDR. 50,000 per day. So in 3 months the ABK's income ranges from IDR. 2,700,000 - up to IDR. 4,500,000,000, -. In addition to daily income, ABK also gets an additional income of IDR. 1,500,000, - if you get more than 1 (one) ton of squid. And get a bonus motorbike if you get more than 3 tons. If accumulated in 1 year, the ABK's income ranges from IDR 14,850,000 up to IDR. 32,750,000. 
From the range of income, the expenses of $\mathrm{ABK}$ are also quite large, considering that on average they have had a family, when left to go to sea, according to ABK the need for ABK ranges from IDR. 15,150,000 to IDR. 26,400,000 per year. With the amount of expenditure, the ABK is difficult to fulfill their needs.

Simultaneously the three variables were tested, so based on the calculation of SPSS Version 25.0 obtained Fcount of 104.147 with a significance value of 0.000 . The value of $F$ table from the statistical table is table F with df1 $=3, \mathrm{df} 2=36$ and alpha $5 \%$, and the value of Ftable is 2.866 . Thus, it is known that Fcount $(104,147)>$ Ftable $(2,866)$ or significance value $(0,000)<0.05$ so that $\mathrm{H} 0$ is rejected. This shows that fuel costs, logistic costs and the number of employees are affected simultaneously on capture income.

When going to sea, the crew is headed by a captain, a mechanic, a cook and members detailing the costs of going to sea. For ships with a capacity of 29 GT, the captain proposes a supply and fuel cost of IDR. $518,000,000$ per trip. For ships with large capacity, $196 \mathrm{GT}$, the captain proposes supplies and fuel costs of 1,175 billion per trip.

\subsection{Feasibility of Capture Fisheries}

Benefit Cost Ratio. Based on the calculation results it is known that the $\mathrm{R} / \mathrm{C}$ ratio is 1.89 which means that the capture fisheries business is said to be efficient. The value of Benefit Cost Ratio is 1.17 which means fisheries business in PPN Kejawanan, Cirebon is worth trying.

\subsection{Break Event Point}

Based on the results of the calculation it is known that Break Event Point capture fisheries business is 2.59 years. This means that with the productive age of fishing vessels for 25 years, a short Break Event Point means that capture fisheries are profitable businesses.

\section{Conclussion}

a. The growth of capture fisheries in PPN Cirebon city championship period 2013-2017 as a whole has increased. Catch growth follows a regression equation model: $\mathrm{Y}_{\mathrm{t}}=15172,200-3826,500 \mathrm{~T}+2103,000 \mathrm{~T}^{2}-238,500 \mathrm{~T}^{3}$.

b. Capture fisheries income (IDR / year) is influenced by variable size of ship (Gross ton), cost of fuel (IDR / year), cost of debt (IDR / year) and number of crew (people) by following the regression model: $\mathrm{Y}=-309,369+6,049 \mathrm{X}_{1}+0,777 \mathrm{X}_{2}+0,069 \mathrm{X}_{3}+73,012 \mathrm{X}_{4}+\varepsilon$

c. . Capture fisheries is an efficient and viable business. With a productive age of 25 years fishing vessel and Break Event Point of 2.59 years, it means that the re-investment in capture fisheries is relatively short. 


\section{References}

[1] Juwarti. 2003. Analisis Faktor-Faktor yang Mempengaruhi Hasil Tangkapan Ikan Laut di Pandansimo Kabupaten Bantul. Yogyakarta: Universitas Gadjah Mada.

[2] M. S. Wardani, A. Ghofar, and S. W. Saputra. 2013. "Efektifitas Fasilitas Pangkalan Pendaratan Ikan (PPI) Pasir Dalam Pengelolaan Sumberdaya Perikanan Di Kabupaten Kebumen," Management of Aquatic Resources Journal, vol. 2, no. 2, pp. 87-92

[3] N. Sudirman, S. Husrin, and R. Ruswahyuni, "BAKU MUTU AIR LAUT UNTUK KAWASAN PELABUHAN DAN INDEKS PENCEMARAN PERAIRAN DI PELABUHAN PERIKANAN NUSANTARA KEJAWANAN, CIREBON (Water Quality Standards For Port Area And Water Pollution Index In Fisheries Port Kejawanan, Cirebon)," SAINTEK PERIKANAN, vol. 9, no. 1, pp. 14-22, 2013.

[4] B. Budiman, S. Supriharyono, and A. Asriyanto, "ANALISIS SEBARAN IKAN DEMERSAL SEBAGAI BASIS PENGELOLAAN SUMBERDAYA PESISIR DI KABUPATEN KENDAL ," Jurnal Pasir Laut, vol. 2, no. 1, pp. 52-63, 2006.

[5] S., \& Rustikawati, I. Alhuda, "Analisis produktivitas dan kinerja usaha nelayan purse seine di Pelabuhan Perikanan Pantai Lempasing, Bandar Lampung," Jurnal Perikanan Kelautan, vol. 7, no. 1, 2016.

[6] Joko Suwarno, "Gerakan Muncar Rumahku'dan Strategi Mobilisasi Sumber Daya Pada Gerakan Sosial Penyelamatan Lingkungan," Jurnal Pemikiran Sosiologi, vol. 3, no. 2, pp. 17-25, 2016.

[7] E., Gaol, J. L., \& Siregar, V. P. Putra, "Hubungan konsentrasi klorofil-a dan suhu permukaan laut dengan hasil tangkapan ikan pelagis utama di Perairan Laut Jawa dari citra satelit modis," Jurnal Teknologi Perikanan dan Kelautan, vol. 3, no. 2, pp. 1-10, 2012.

[8] M. T., Djasmani, S. S., Saksono, H., \& Suadi, S. Utomo, "ANALISIS USAHA PURSE SEINE DI KECAMATAN JUWANA KABUPATEN PATI," Jurnal Perikanan Universitas Gadjah Mada, vol. 15, no. 2, pp. 91-100, 2011.

[9] A. M. Yusuf, Metode penelitian kuantitatif, kualitatif \& penelitian gabungan.: Prenada Media, 2016.

[10] William G. Cochran, Teknik Penarikan Sampel. Jakarta: UI Press, 1991.

[11] Taro Yamane, Elementary Sampling Theory. Englewood City, New York: Prentice Hall. Inc, 1967.

[12] Bilson Simamora, Panduan Perilaku Pelanggan. Jakarta: PT. Gramedia Pustaka Utama, 2012. 